\title{
Politisk og religiøs identitet blant kurdere i det syriske Jazira
}

\section{Kurderes svar til Assad-regimets diskriminering og ekskluderende politiske strukturer, splitter det syrisk-kurdiske samfunnet.}

Av Even Nord Rydningen, master i sosialantropologi fra Universitetet i Bergen.

\begin{abstract}
DENNE ARTIKKELEN vil fremstille original empiri om de tydeligste linjer for ideologisk uenighet - og dermed potensielle kilder til utvikling og endring - blant kurdere i syriske Jazira (heretter Jazira). Linjene plasserer kurdere i tre politisk-religiøse miljøer eller identitetsgrupper: sekulornasjonalististene, islamfundamentalistene og nasjonalislamistene. Jeg vil ikke ta for meg de partipolitiske skillelinjene i kurdiske Syria, da disse i høy grad er trukket opp etter personlige konflikter og stammelinjer. ${ }^{\mathrm{t}}$
\end{abstract}

\section{Metode}

Artikkelen bygger på et fire måneders feltarbeid utført i Jazira i 2008. Bosatt i en moské i landsbyen Helwa Shaykh, med gode arabiskkunnskaper og et betydelig nettverk fra tidligere opphold i landet, hadde jeg gode forutsetninger for å drive deltakende observasjon og intervjue. Den spente sikkerhetssituasjonen i regionen, herunder etterretningsvesenets gjennomsyring av samfunnet, var en betydelig utfordring i forhold til informasjonsinnhenting. Sikkerhetssituasjonen hindret meg imidlertid ikke å innhente empiri som er representativ for Jaziras kurdiske befolkning. ${ }^{2}$ Jeg har intervjuet og observert et hundretalls informanter, herunder flere aktivister i de syrisk-kurdiske partiene, et knippe religiøse ledere, landsbybeboere fra et titalls landsbyer spredt utover fra Qamishli i vest til Malikiya og Ain Diwar i øst, så vel som advokater og en dommer i Malikiya tinghus.

\section{Arabisering av Syria og Jazira-regionen}

Før jeg tar for meg empiri innsamlet under feltarbeidet, er det nødvendig å se på sider av 


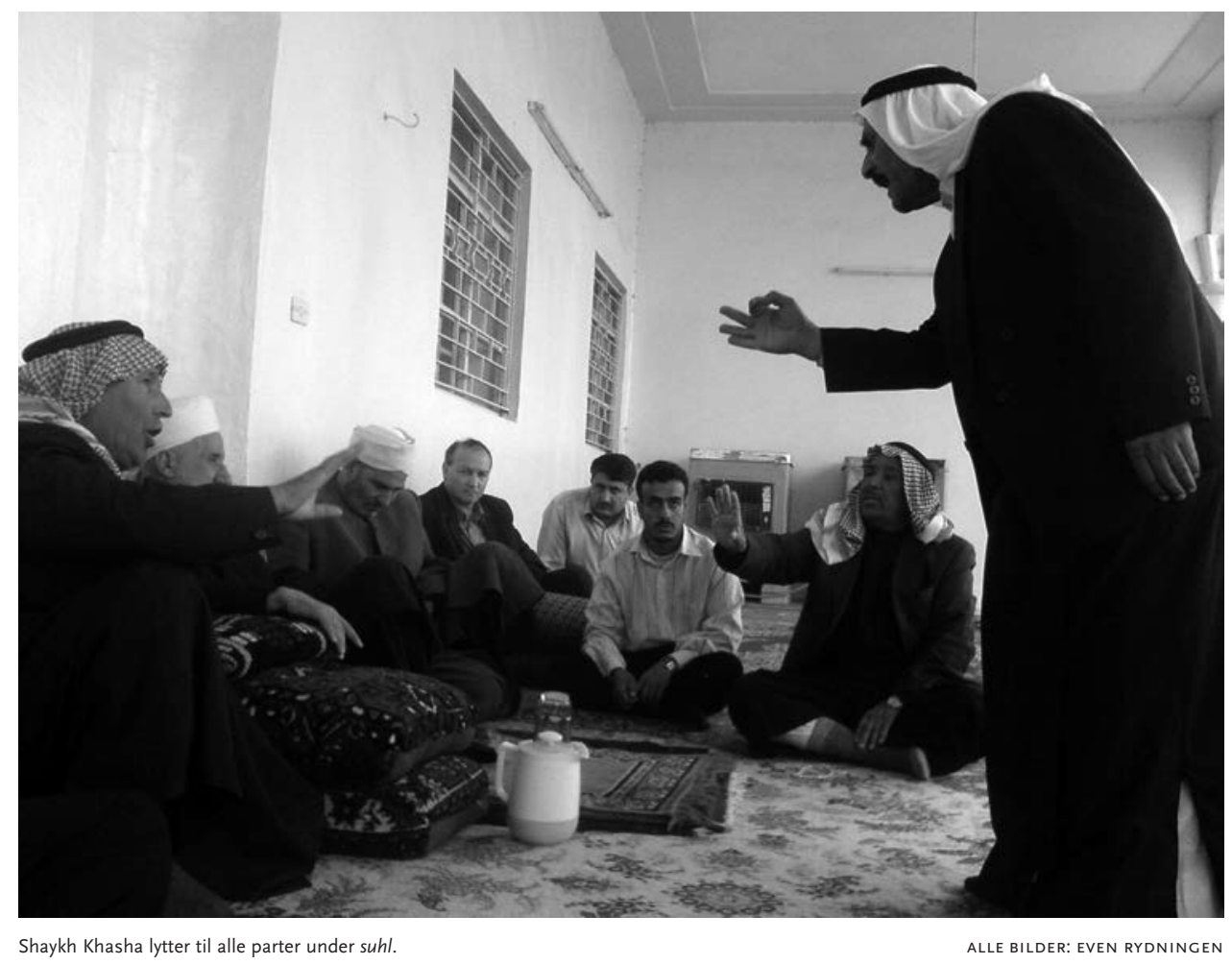

den politiske konteksten i Jazira-regionen. Innsikt i den politiske konteksten er viktig for å forstå kurdiske identiteter fordi disse langt på vei har utviklet seg som svar på nasjonalstaters politikk. ${ }^{3}$

I I96I skiftet Syria navn fra Den syriske republikk til Den syrisk-arabiske republikk. Navneskiftet ble fulgt opp av politiske tiltak som bekreftet den arabiske befolkningens prioriterte posisjon i Syria. Den femte oktober I962 fant en spektakulær folkeopptelling sted. Da ble anslagsvis $1200^{4}$ kurdere i den nordøstlige Hassaka-provinsen i Syria fratatt statsborgerskap. Begrunnelsene som ble gitt var mange. Den vanligste årsaken var at et familienavn ikke ble gjenfunnet i statens registre over familier som var tilknyttet regionen. Personer uten slik familietilknytting, ble registrert som syriske utlendinger (ajnabi surii).
Syrias nye «utlendinger» mistet rettigheter som er knyttet opp mot statsborgerskapet, blant annet retten til privat eierskap, til å jobbe i statssektoren, til å motta offentlige tjenester og til å reise ut av landet. Jordreformer som ble gjennomført i I970 fratok «utlendingene» jorda de hadde dyrket. Reformen fungerte således til å marginalisere kurdere ytterligere. Antallet «utlendinger» vokste til over 300000 før president Assad i april 20II tilkjente «utlendingene» statsborgerskap og rettighetene som er knyttet til det, gjennom et dekret.

I0० 000 kurdere forblir imidlertid uregistrerte. Al-maktumin (de bortgjemte, skjulte) har i enda større grad enn al-ajanib (bestemt flertall av ajnabi), vært marginaliserte, og er ikke omfattet av overnevnte dekret.

Fra slutten av I960-årene og fram til 1976 
ble jordprogrammet «Det arabiske beltet» implementert. Jordreformen var ment å tilby arabiske innflyttere til Jazira jord og gårder, og virket svekkende på samhørigheten mellom kurdere i Syria og kurdere i Tyrkia. Innflytterne utgjør i dag et arabisk belte, et område som er 375 kilometer langt og ti kilometer bredt, og strekker seg over Syrias mest fruktbare jord langs den syrisk-tyrkiske grensen. Dette er jord som tidligere tilhørte den lokale kurdiske befolkningen. ${ }^{5}$

Jeg vil i det følgende presentere et utvalg av egne og informanters observasjoner, som synliggjør sentrale konfliktlinjer blant Jaziras kurdere. Kategoriene som skisseres, er identitetskategorier som relaterer så vel til følelser av tilhørighet som til interesser og ideologi, og favner brede lag av Jaziras kurdere.

$$
\odot \odot \odot
$$

"Vi ser på arabere med svarte øynefordi de nekter oss retten vår. Landets sanne folk spiser ikke."

$$
\odot \odot \odot
$$

Med islamisme mener jeg «a form of instrumentalization of islam by individuals, groups and organizations that pursue political objectives». ${ }^{6}$ Islamisters mål er ikke først og fremst teologiske, men revolusjonær forandring av statsstruktur og lovverk.

Med islamsk fundamentalisme refererer jeg til en iverksettelse av islam som har teologiske mål som sitt primære anliggende. Islamske fundamentalister unngår generelt deltakelse i det politiske ordskiftet og utfordrer sjeldent regjeringer. De søker å skape et konservativt islamsk samfunn «innenifra» ved å fokusere på saker som har med moral og sosiale relasjoner å gjøre, herunder implementering 96 og streng etterfølgelse av sharia.7 Islamfundamentalistene likner på mange måter salafister. Men islamfundamentalistene som trekkes frem her, gir betydelig oppmerksomhet til flere ritualer som kan assosieres med sufisme. Disse ritualene inkluderer ulike former for ihukommelse av Gud (dhikr) som sang og meditasjon. Jeg velger derfor å holde kategoriene «islamfundamentalisme» og «salafisme» adskilt.

\section{Helwa Shaykh}

Landsbyen der jeg gjorde feltarbeidligger på det arabiske beltet, tjue kilometer øst for Qamishli og ti kilometer sør for grensa til Tyrkia. Landsbyen er på mange måter en ordinær kurdisk landsby i Jazira, bestående av omtrent åtti hus hvorav de fleste er reist på strå og leire. Det er en religiøst og språklig homogen landsbybefolkning (kurmanji-talende sunnimuslimer) som i all hovedsak livnærer seg på jordbruk og husdyrhold. Landsbyen inneholder en moské, en barneskole, et brødbakeri, tre små utsalgssteder av de enkleste basisvarer og en fotballbane. Ingen av gatene $\mathrm{i}$ landsbyen er asfalterte, og det finnes kun få lamper som lyser opp nattestid. Et fåtall av landsbybeboerne har biler, mens samtlige husholdninger har tv med parabolantenne. Jorda som omringer landsbyen er ekspropriert til nabolandsbyen, Helwa Jadida (Nye Helwa), som bebos av arabiske innflyttere. Befolkningen i Helwa Shaykh har fått erstattet tapet med jord lenger sør, hvor det knapt kan drives jordbruk grunnet vannmangel og saltholdig jord.

Helwa Shaykh skiller seg fra andre landsbyer ved at den er en relativt viktig landsby. Dens viktighet stammer fra faren til den

\footnotetext{
To eldre menn i landsbyen Helwa Shaykh.
} 
POLITISK OG RELIGIøS IDENTITET BLANT KURDERE I DET SYRISKE JAZIRA

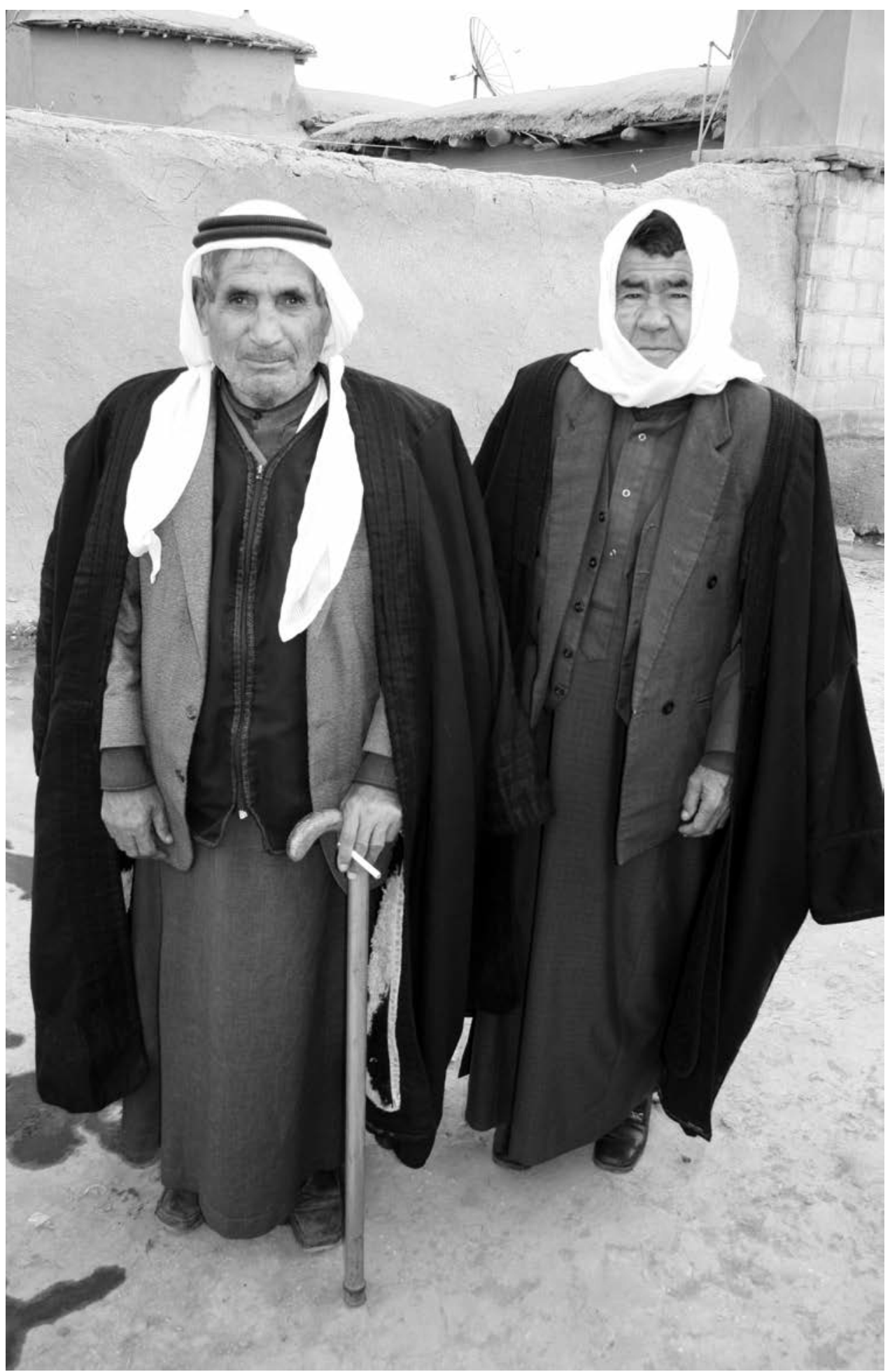


nåværende «kalif» i landsbyen, Shaykh Ibrahim Haqqi. Ibrahim Haqqi flyktet fra Tyrkia til Irak i i924, og slo seg ned i Helwa med familie i I938. Med shaykh Ibrahim forvandlet Helwa seg fra å være en ordinær boplass for bønder til å bli sete for en av Jaziras mektigste sufi-shaykher, et sentrum for shaykhens stadig større skare av tilknyttede; et «mikrokalifat». De arabiske og kurdiske stammene i området tok disputtene sine til shaykhen for å få dem løst. Fredagsbønnene tiltrakk seg folk langveisfra, skårer av gjester kom for å besøke shaykhen og studenter slo seg ned i moskeen for å studere. Med sin utstrakte innflytelse, likner sufi-lederen på andre kurdiske sufier som opp gjennom historien har spilt viktige sosiale og politiske roller i de kurdiske områdene. ${ }^{8}$ «Kalifatet» som shaykh Ibrahim stiftet har blitt videreført av fire av hans ti sønner (posisjonen som «kalif» er arvelig, slik det er vanlig i «Kurdistan»), ${ }^{9}$ og nåværende kalif er shaykh Khaasha. På fredager og helligdager fylles moskeen av mennesker, arabere så vel som kurdere, hvorav de fleste kommer utenfra. Stadig søker partene i en konflikt til shaykhen og moskeen for å løse konflikter. Et varierende antall studenter bor i moskeen og undervises av shaykhen til enhver tid, mens mange kommer innom for kortere eller lengre perioder. Mye av aktiviteten som tidligere fant sted i moskeen finner stadig sted, men omfanget er i dag sterkt redusert. Vi skal nå se hvorfor.

\section{Sekulærnasjonalistene}

Jeg er på besøk hos en eldre herre i landsbyen når Abdullah, en snekker i førtiårene, og hans sønn stikker innom. Flere stoler hentes frem, te blir trukket, og far med sønn tar seg en hvil etter endt arbeidsdag. Abdullah, viser det seg, har viktige ting på hjertet, som han tar til å dele med meg: "Livet her er vanskelig, vi har ingen rettigheter, ingen frihet." Utsagnet, som uttrykker misnøyen som mange uttrykker på landsbygda i Jazira, kommer uten at jeg har stilt spørsmål. "Se på demonstrasjonen i Qamishli går: Et menneske ble myrdet i en

$$
\odot \odot \odot
$$

"Når det kommer til politikk liker vi ikke shaykhene våre, for de forsvarer ikke folket sitt."

$\odot \odot \odot$

fredelig demonstrasjon! Slagordet deres var 'Nei til tyrkisk-syrisk samarbeid' [om å slå ned på PKK i Irak].” Abdullahs toneleie er høyt, stadig tiltagende: "Kurdere er de fredligste av folk, vi blir drept og plyndret, men hevner oss aldri. Arabere derimot, har en uhyre svak evne til fred." Jeg spør: "Alle arabere er vel ikke sånn?" “Nei, ikke alle”, sier han, “85 prosent er sånn."

Abdullah utdyper sine fremmedfiendtlige holdninger idet jeg spøker med at jeg skal delta i de kurdiske demonstrasjonene og skli ubemerket inn ved å kle meg i kafiyya og agal (hodeplagg). Han avbryter alvorlig: "Ikke kle deg i kafiyya og agal! Det er arabisk.” Alvoret i tonen hans og den biske artikuleringen av «arabisk», insinuerer at han fraråder meg å bruke plagget - ikke fordi det ville ha avslørt at jeg ikke er kurder - men fordi det tilhører en slags fiendens drakt. Hodetplagget, som for meg var et sjal og en festemekanisme, et klesplagg som bæres av kurdere så vel som arabere, var for Abdullah et ladet symbol som kommuniserte tilhørighet til en motpart. Abdullahs fritale fremmer min egen: "Jeg har funnet mye rasisme og fremmedfiendtlighet blant kurdere. Hat mot arabere, tyrkere, persere og palestinere." Observasjonen min 


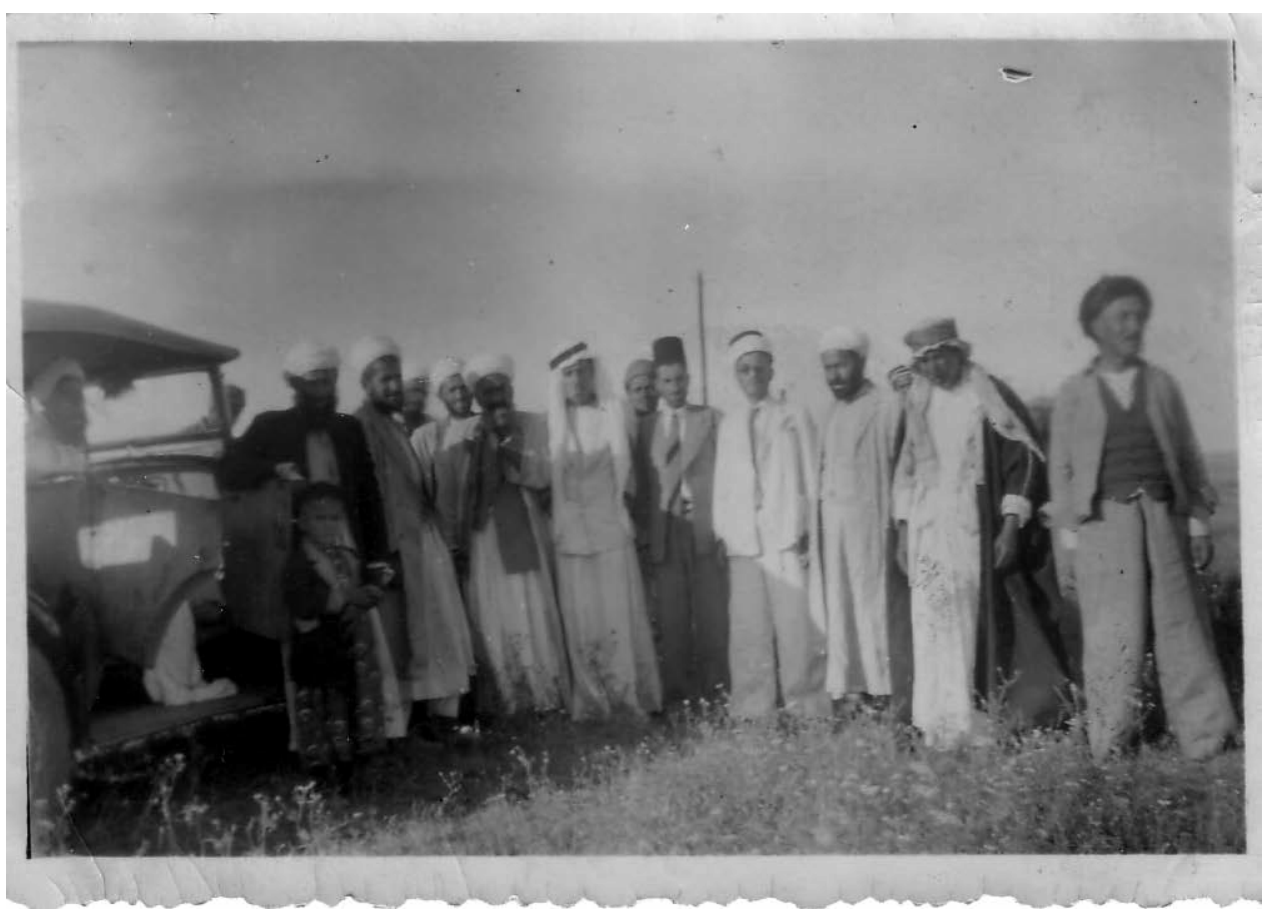

Shaykh Ibrahim, faren til shaykh Khasha, helt til venste i bildet. Foto fra rundt 1930.

ville av mange blitt forsøkt bortforklart, men Abdullah anerkjenner den som et faktum og presiserer: "Vi ser på dem [arabere] med svarte øyne - fordi de nekter oss retten vår! Vi blir nektet vår rett! Landets sanne folk [kurdere] spiser ikke, mens dets usanne folk [arabere] spiser. Vi er døende her. Dette området er fortapt! Enten Kurdistan, eller død kurder!”

Jeg spør de tre andre som sitter rundt bordet og har fulgt samtalen om de er enige i hva Abdullah sier. "Alle kurdere er enige!" svarer eldste sønnen i huset kontant. Abu Khadija, far i huset, nikker bekreftende. "Vi liker ikke shaykhene fordi de ikke forsvarer rettighetene våre!" skyter Abdullah inn. "De taler ikke den kurdiske saken, tar ikke opp kampen mot urettferdighetene. Shaykh Khaznawi ble drept for to år siden fordi han reiste seg mot tyranniet. Han var en sann shaykh!" Shaykh Khaz- nawi var lenge en sentral talsmann for kurderes rettigheter, en uredd kritiker av Baathregimet og en karismatisk sufi-leder bosatt $i$ Til Maruf, ikke langt fra Qamishli. Han «forsvant» i 2005 da han kom tilbake til Syria etter å ha deltatt på diverse menneskerettighetsseminarer i Europa, deriblant Oslo.

Jeg prøver å bekrefte at jeg har hørt riktig. "Vi liker ikke shaykhene?" Denne eksplisitte fordømmelsen av shaykher, inkludert landsbyens egne prominente shaykh Khaasha, overrasker meg. Mens jeg noterer ned uttalelsen som forkaster mine forestillinger om shaykhenes nærmest ubestridte og opphøyde status på landsbygda i Jazira, lener Abu Khadija seg mot Abdullah og hvisker noe inn i øret hans. Av det som blir sagt oppfatter jeg bare at informasjonen han formidler ikke er ment for mine ører, og at Abu Khadija har 
reagert på noe som Abdullah har sagt. Når jeg folder blokka mi sammen, korrigerer den frittalende: "Vi liker shaykhene våre, vi setter pris på dem, men når det kommer til politikk liker vi dem ikke, fordi de ikke forsvarer folket sitt!”

Istedenfor å vie seg til religionen deltar Abdullah, i likhet med det jeg oppfatter å være et flertall av kurderne i Jazira, i den kurdiske nasjonalbevegelse. Hans kamp er for kurderes rettigheter, hans primære fellesskap er et kurdisk fellesskap, og hans høyeste drøm er et selvstendig Kurdistan. Gjennom de siste seks årene har han vært aktiv medlem av et av de største kurdiske politiske partiene i Syria, Yeketi. Han bidrar med distribusjon av partiavisa, og deltar i demonstrasjoner, kulturelle begivenheter, på debatter og møter. Han forherliger ideen om et selvstendig Kurdistan, deltar på alle arrangementer som har en kurdisk agenda og anser kurdere som ikke identifiserer seg med og ikke deltar i den kurdisk nasjonalistiske bevegelsen som svikere. Videre hyller han Ariel Sharon og Abu Hurriyya (Frihetens Far - George W. Bush) på grunn av deres fiendtlige forhold til den syriske statsmakt, og han er gjerne blant dem som bærer plakater av disse «heltene» under kurdiske demonstrasjoner i Qamishli. Han bespotter den kurdiske hærføreren Saladin og anser ham for å være en sviker mot kurdere fordi hærføreren handlet som en islamsk leder framfor som en kurdisk leder. ${ }^{\circ}$

Perspektivene på disse historiske lederne, skal vi merke oss, gir signaler om ekstremistiske tendenser i det sekulær-nasjonalistiske miljøet. Synet på Saladin som en forræder, et syn jeg møtte ved flere anledninger, er et eksempel på dette. Nasjonalisme og etnonasjonalisme er biprodukter av moderne statsdannelse (I80o-tallet og utover). ${ }^{\text {II }}$ På ııo-tallet under Saladins tid, eksisterte altså ikke etnisk motivert politikk: identiteten «kurder» var ingen kilde til politisk kamp, den kurdiske nasjon var ennå ikke forestilt eller tatt form. A fordømme Saladin fordi han ikke handlet eksklusivt på vegne av det kurdiske folk, er derfor en anakronisme. Videre er den en påstand som peker mot mange av dagens kurdiske nasjonalisters veldige innbitthet til sin kurdiske identitet. Ekstremt ekskluderende holdninger er en sentral årsak til at andre kurdere underspiller sin kurdiske identitet og vender ryggen til nasjonalbevegelsen.

“Sekulærnasjonalismen" - i all sin heterogenitet - oppfatter jeg som den mest utbredte type nasjonalisme eller brede politiske orientering som kurdere i Jazira kan identifiseres med i dag. Utenfor det religiøse nettverket jeg opparbeidet meg gjennom moskeen, uttrykte et stort flertall ideer som er sammenfallende med sekulærnasjonalismen. Det lød videre unisont fra kurdere av den mer konservative islamske leiren, fra arabere eller fra kurdere som tok avstand fra kurderes nasjonale entusiasme, at de mislikte den kurdiske nasjonalismen fordi den var «rasistisk» og «islamfiendtlig». Av disse ble kurdisk nasjonalisme gjennomgående omtalt som én bevegelse, som korresponderer med det jeg omtaler som sekulærnasjonalismen. Alternativet, nasjonalislamismen, ble nærmest ikke nevnt når folk utenfor de kurdisk nasjonalistiske strømninger omtalte kurdisk nasjonalisme. Dette alternativet, altså en ikke-islamfiendtlig nasjonalisme, skal vi komme tilbake til. Men for å forstå hvordan den forener to ideologier, må vi først se på det islamske motstykket til sekulærnasjonalismen.

\section{Islamfundamentalistene}

Religion i Syria er kontrollert og langt på vei appropriert av staten. Avskåret fra evnen til å 
endre det politiske systemet, yter shaykh Khaasha engasjement i de mer «sivile» sfærer. Typiske arenaer hvor islamfundamentalistene bedriver sitt virke er moskeer, private hjem, telt som slås opp i anledning bryllup eller begravelse, og stundom tv eller radio. I disse arenaer er fundamentalistene særlig engasjert i arbeidet med å tegne opp sosiale relasjoner etter islamske anvisninger, oppdra folk i islamsk moral og til å produsere en slags islamsk sosial bevissthet.

Den konservative sosiale orden som manifesterte seg i Helwa Shaykh til daglig, peker mot shaykhens betydelige innflytelse på lokalsamfunnet. Jenter var fraværende i lands-

$\odot \odot \odot$

"Hvis jeg hadde hadde handlet, ville folk ha snakket. Det regnes som en skam for ugifte kvinner å gå ut."

$\odot \odot \odot$

byrommet, og en informant fortalte meg at hun aldri gikk ut, ikke engang for å kjøpe grønnsaker av grønnsaksbilen som frekventerte landsbyen. "Hvis jeg hadde handlet ville folk ha snakket, gjort oss til skamme. Det regnes som en skam for ugifte kvinner å gå ut." Et annet viktig tegn på shaykhenes vedvarende innflytelse i det syrisk-kurdiske samfunn, er deres viktige, om ikke lenger suverene, rolle i sivile konfliktløsningsprosesser (sulh). Shaykh Khaasha og andre eldre i hans familie ble opptil flere ganger i uken oppsøkt av personer som ønsket deres megling og dom i konfliktsituasjoner som skilsmissesaker, jorddisputter og alvorlige æressaker. Shaykhene dømmer etter sharia, og blir foretrukket av et stort antall kurdere og arabere framfor det statlige rettsvesenet på denne bakgrunn, samt fordi de løser konflik- ter hurtig, gratis og ikke lar seg bestikke. Fremveksten av den kurdiske nasjonalbevegelsen har imidlertid ført til at nye autoritetsfigurer har tiltrådt viktige posisjoner i sulh. I sivile konfliktløsningsprosesser som inkluderer en eller flere kurdiske parter, var alltid representanter for de kurdiske partiene til stede som meglere og dommere. ${ }^{12}$

Det lave antallet moskégjengere, kritikken som haglet mot kurdernes egne religiøse ledere, og shaykhenes tap av rollen som suverene dommere i sulh-prosesser, peker mot shaykhenes og fundamentalistenes fallende popularitet. Fallet skyldes i vesentlig grad deres forhold til politikk: den røde linja som avgrenser fundamentalistenes engasjement går ved politikk på statlig nivå. Det betyr at fundamentalistene avstår fra forsøk om å påvirke det syriske lovverket og at de avstår fra deltakelse i den offisielle politiske ordvekslingen. Fundamentalistene søker heller ikke overtakelse av statsmakt. Et viktig kjennetegn ved fundamentalismen, et kjennetegn som skiller den fra nasjonalistmiljøene, er dermed at dens agenter søker å oppfylle sine idealer innenfor - og uten å konfrontere - eksisterende makropolitiske strukturer. Det er relevant å sitere Duktuh Habash her, en progressive islamsk politiker og uavhengig medlem av den syriske nasjonalforsamlingen: "The conservative direction in Syria has no political agenda at all. They prepare for life after death and observe strict traditions and values." ${ }^{13}$ Uttalelsen beskriver konservative krefter på en måte som tilsvarer min definisjon.

Som følge av fundamentalistenes forhold til politikk, har store antall av den politiserte, kurdiske befolkningen vendt ryggen til de religiøse lederne og religionen de gjør representasjonskrav på. Kritiske holdninger til religionen og dens autoritetsskikkelser har skapt 
dyp splid i den kurdiske befolkningen som tradisjonelt har sterke bånd til islam og det religiøse lederskapet.

Gjennom iverksetting av «muslim» som primær identitet, underkommunisering av den kurdiske identitet, boikott av den kurdiske nasjonalbevegelse, forherligelse og forfekting av en sosial orden av den islamske gullalder, vekt på sosiale relasjoner og moral, demonisering av Vesten, ivaretakelse av et gjensidig positivt forhold til statsmakten og avstand fra engasjement $i$ den statlige politiske sfære, står fundamentalistene i diametralsk opposisjon til sekulærnasjonalistene. De to miljøene er gjensidig ekskluderende.

Der det finnes en tese og en antitese, finnes ofte en syntese. Så også når det gjelder diskurser om religiøs og politisk identitet blant kurdere i Jazira. Etter å ha skissert to radikalt forskjellige miljøer, skal vi se på en tredje orientering som langt på vei forener de foregående.

\section{Nasjonalislamistene}

- Det finnes fem typer nasjonalisme. Aduaniyya og jahiliyya - og disse to forkastes av islam - og majd, aza og tauniyya, som anerkjennes av islam. Den første typen er en nasjonalisme der man giør et folk til fiende av den simple grunn at det ikke er ens eget folk. Den andre typen er en nasjonalisme som forfektes av et folk som har «primitive» eller «underutviklede» skikker og tradisjoner. Den tredje typen er en nasjonalisme som bygger på stolthet og glede over ens folk, over historien og skikkene/tradisjonene deres. Den fjerde typen er en nasjonalisme som handler om å lede et folk ut av undertrykkelse. Den siste typen er nært beslektet til den foregående, og handler om å forsvare ens folk.

Ordene tilhører mulla Abdulla (84 år), en dedikert kurdisk nasjonalist og anerkjent muslimsk teolog. I likhet med medlemmene i Haqqi-familien er han bosatt i Qamishli, og ankom Syria fra Tyrkia på tjuetallet. Feltarbeidet mitt bød på flere møter med mennesker som regner seg som nasjonalister så vel som praktiserende muslimer, men mullaen står fram som særegen blant disse: han er en høyt utdannet, høyttalende, respektert og fri kurdisk nasjonalist. Andre skikkelser som har autoritet og som ytrer seg offentlig om løsrivelse fra Syria, blir effektivt håndtert av myndighetene.

"Hvis han hadde vært like viktig som shaykh Khaznawi var, ville myndighetene tatt ham av dage", forklarer Imam, en nevø av shaykh Khasha meg, og informerer med det om grensene for mullaens innflytelse. "Han er dessuten så gammel at det regnes som synd å sette ham i fengsel. Han vil snart henfare, så myndighetene lar ham være i fred. De regner ikke med at han får stelt $\mathrm{i}$ stand betydelige problemer." Mulla Abdullah har tidligere sittet fengslet $\mathrm{i}$ to perioder på grunn av sin kamp for kurderne, og har blitt fratatt tillatelsen til å tale i moskeer.

Det er relevant å nevne at to høyt utdannede, det jeg oppfattet å være velinformerte informanter, hevdet at det var et velkjent faktum at syriske myndigheter eliminerer shaykher som taler kurdernes sak.

Den sjeldne kombinasjonen av karaktertrekk som mulla Abdullah innehar (høyttalende, respektert og fri kurdisk nasjonalist), kombinerer han med rollen som mudarris (lærer i islamske vitenskapsgrener) og mufti (islamsk rettslærd). Da jeg spurte shaykh Khasha om mullaen, kunngjorde han med dempet toneleie og et blikk som fikk hans enkle ord til å yte stor kraft, at mullaens kunnskap var “sterk, veldig sterk!” På grunn 
av mullaens kamp for kurdere, hevdet tidligere nevnte Abdullah at han var en av få religiøse autoriteter som hadde forstått islam.

"Er ikke nasjonalisme, en ideologi som normalt trekker politiske grenser mellom etniske grupper, i konflikt med det islamske idealet om å inkludere ulike grupper i ett religiøst fellesskap", spør jeg en dag vi tilbringer i huset hans.

"På grunn av Amerika og Europa er det vanskelig å realisere den islamske staten, men vi må frigjøre oss fra undertrykkelsen", svarer mullaen. Han resiterer så fra koranen, sura Al-Baqara, vers 243: "Du kjenner vel til dem som forlot sine hus i dødsfrykt? Gud sa til dem, 'dø!' Senere vekket Han dem til live igjen." ${ }^{{ }_{14}}$ Verset trekkes ofte fram for å oppfordre muslimer til å kjempe for Guds vilje. Jeg antar mullaens hensikt med å trekke fram verset var å vise til det han tolket som Guds oppfordring til kurdere om å kjempe mot undertrykkelse, til ikke å gi opp kampen for sin rett, på tross av kampens potensielle høye pris. “Ikke ett folk skal være under et annet!" Mullaen utstråler en mild og ydmyk autoritet, som om generert av en slags indre fred mer enn av sinne og skuffelse. Han resiterer fra Koranen igjen, sura al-Mumtahana, vers 8-9: “'Gud forbyr dere ikke å vise respekt og rimelighet mot dem som ikke bekjemper dere for religionens sak, og ikke drev dere bort fra deres hjem. Gud liker dem som viser rimelighet: Gud forbyr dere bare at dere slutter dere til dem som bekjempet dere for religionens sak, og drev dere bort fra deres hjem eller hjalp til ved utdrivingen'. Islam gjør det ikke ulovlig å forsvare seg mot sine undertrykkere."

Jeg trekker fram kurdere med gode jobber, kurdere som er leger, advokater og handelsmenn, og kurdernes dominerende posisjon $\mathrm{i}$ handelsstanden i Qamishli, det kurdiske hegemoniet i religion i Syria og kurdernes på mange måter - gode og stadig bedre situasjon i Syria. Lider egentlig kurderne under dårligere kår enn arabere flest? Er virkelig kurderne i Syria så undertrykte?

"Utvilsomt! 375 o0० kilometer multiplisert med Io-2o kilometer jord har blitt tatt i fra oss. De har tatt statsborgerskap og rettigheter fra oss. De forbyr oss å studere kurdisk og å lære om oss selv. Fra I925 til I928 drepte

$$
\odot \odot \odot
$$

"De har tatt statsborgerskap og rettigheter fra oss. De forbyr oss å studere kurdisk og loere om oss selv."

$\odot \odot \odot$

Tyrkia I,5 millioner kurdere, og fra I928 til I942 drepte de ytterlig I,5 millioner. Det finnes ikke et folk blant verdens seks milliarder mennesker som er mer undertrykte enn kurdere! Og undertrykkelse er ulovlig i religion!" Han resiterer sura An-Nisa, vers 44: "Gud gjør ikke et støvkorn urett."

"Så du er religiøs og nasjonalist?” konkluderer jeg tentativt.

"Jeg er ikke religiøs og nasjonalist! Forsvar av ens folk er en del av religionen, en religiøs plikt."

Nasjonalisme, for mulla Abdullah, er det redskapet, som, gitt dagens viktigste krise (kurdernes situasjon) og globale politiske spilleregler (nasjonalstaten som legitim politisk entitet og vestlig hegemoni), må iverksettes for å oppfylle sentrale islamske imperativer (forsvar av ens folk). Blant de mulige svar på disse innsnevrende premisser og presserende krav, finner altså mullaen at det mest korrekte er nasjonalisme. Man kan imidlertid innvende at det islamske idealet er et fellesskap som bygger på felles religiøs iden- 
titet og som integrerer ulike etniske grupper, mens den kurdiske nasjonalismen trekker politiske grenser nettopp mellom gruppene som islam ønsker å integrere. Svaret, altså nasjonalislamismen, bør forstås som et kompromiss mellom politiske realiteter og religiøse krav, en nødhandling med noe bismak, og ikke, slik det har blitt skrevet om islamisme tidligere, ${ }^{15}$ som en del av den islamske tro.

Kombinasjonen av et solid engasjement for islam og en dyp interesse for og identifisering med det kurdiske folk, er en holdning som gjennom historien har vært utbredt blant kurdiske mullaer.

Mulla Abdullah og hans assosierte slutter seg til denne holdningen, i kontrast til shaykh Khaashas og fundamentalistenes mer ensidige ummah-perspektiver på identitet og tilhørighet. Holdningen står samtidig i kontrast til sekulærnasjonalistenes mer ensidige vektlegging av kulturelle bånd, språkbånd og avstamming. Vi kan si at mullaen representerer en dualistisk identitet, en identitet som er sammensatt av følelser av tilhørighet til og identifisering med et distinkt kurdisk fellesskap så vel som et distinkt islamsk fellesskap.

Denne dualistiske kurdisk-muslimske identiteten er interessant med tanke på ideologiens appell til kurdere. Som et både islamsk og kurdisk prosjekt inkluderer nasjonalislamismen både fundamentalistene (personer hvis primære identitet er «muslim», og som fokuserer på sosiale relasjoner og moral) og sekulærnasjonalistene (personer hvis primære identitet er «kurder» og som anser arbeid for kurderes rettigheter som sitt viktigste anliggende). Den henvender seg altså til individer som tilhører to diametralsk motsatte og konkurrerende miljøer, og med det til det store flertallet av syriske kurdere. Ideologien er syntesen som forener tesen og antitesen, en overordnet orientering som overkommer dype konfliktlinjer i det syrisk-kurdiske samfunnet.

På tross av den brede appellen nasjonalislamismen derfor kan ha, synes den i liten grad å være gjenstand for oppmerksomheten til kurdere. Kurdisk nasjonalisme ble som nevnt generelt sett på som anti-islamsk og antiarabisk av utenforstående individer, og en betydelig andel av kurderne i Jazira synes faktisk å bære på slike holdninger. Ideologien virket $\mathrm{i}$ enda mindre grad å ha materialisert seg $\mathrm{i}$ noen form for organisert bevegelse. Mulla Abdullah er den eneste frittalende ideologen med en viss autoritet som tilhørte den nasjonalislamistiske tilnærming. Hvorfor er ikke denne orienteringen mer utbredt, denne tilsynelatende lærde, forsonende og inkluderende orienteringen? Hvorfor var ikke den nasjonalislamistiske diskursen dominerende blant de kurdisk-nasjonalistiske diskursene?

Svaret kan paradoksalt nok finnes nettopp i orienteringens massemobiliserende potensial. Nasjonalislamismen evner å tiltrekke seg og forene kurdere fra konkurrerende miljøer - å mobilisere brede lag av Syrias nærmere to millioner kurdere. I dette, i dens massemobiliserende potensial, representerer nasjonalislamismen en potensiell farlig opposisjonsbevegelse for Baath-regimet. Regimet, som jeg har gitt eksempler på, håndterer dens proponenter deretter. Det bør nevnes at sheikh Khaznawi, som en muslimsk religiøs lærd og kurdisk politisk aktivist, er naturlig å assosiere med nasjonalislamismen.

Før møtet med mulla Abdullah hadde Imam, nevøen til shaykh Khasha, hevdet overfor meg at han tok avstand fra den kurdiske nasjonalismen. I ettertid korrigerte han:

“Hvis mulla Abdulla er nasjonalist, er jeg også nasjonalist! Jeg støtter også forsvaret av 
kurderne. Men jeg kan ikke fordra de som forkaster islam og som er rasistiske!"

Jeg møtte etter hvert mange som ga uttrykk for de samme holdningene som Imam. Flere signaler tyder på at mulla Abdullas inkluderende ideologi kan favne brede lag av den kurdiske befolkningen dersom den får friere spillerom til å vokse og bli kjent.

\section{Sluttbemerkninger}

Jeg har i det overstående skissert tre religiopolitiske miljøer i kurdiske Syria, samt forholdet dem i mellom. Jeg har argumentert for at store deler av den politiserte, kurdiske minoriteten i Jazira har vendt ryggen til sine tidligere høyt respekterte religiøse ledere, samt religionen som disse forkynner. Dette fordi islam - som plattform for motstand - er sterkt svekket i Syria.

Ideologier og aktører som taler kurdernes sak på en sekulær og til dels anti-islamsk plattform, vinner i denne situasjonen anseelse. Dette skaper splid i en befolkning som tradisjonelt har vært nært tilknyttet religionen og sine religiøse ledere, og det endrer på hva det vil si å være kurder.

Nasjonalislamismen kan ha potensial til å forene de foregående miljøene. Den uttrykker både kurderes religiøse og nasjonale følelser, og er derfor, i møte med en totalitær statsmakt, undertrykket og underutviklet.

Nye politiske realiteter i Syria vil trolig gi rom til betydelig endring av kurderes politiske og religiøse identiteter. Det politiske landskapet vil endres deretter.

\section{$\cdot f \cdot$}

I Rydningen, Even N.: «Kryssende lojaliter, konkurrerende autoriteter - stat, stamme, religion og nasjon blant kurdere i syriske Jazeera». Bergen: Universitetet i Bergen, 2009, S. I4-I5.
2 Ibid, s. 26-36.

3 Garthwaite, Gene R.: "Reimagined Internal Frontiers. Tribes and Nationalism - Bakthiyari and Kurds", i Eickelman, D. (red.): Russia's Muslim Frontiers. New Directions in Cross Cultural Analysis. Bloomington/Indiana: Indiana University Press, I993, S. $130-45$.

4 Tallet er hentet fra rapporten Lynch, Maureen og Ali, Perveen: «Buried Alive: Stateless Kurds in Syria». Washington: Refugees International; Lowe R. 2006. Andre kilder opererer med tall som er opptil dobbelt så høye.

5 Galié, Alessandra og Yildiz, Kerim: Development in Syria: $a$ Gender and Minority Perspective. London: Kurdish Human Rights Project, 2005; Lynch, Maureen og Ali, Perveen: «Buried Alive: Stateless Kurds in Syria». Washington: Refugees International; Lowe R.: The Syrian Kurds: A People Discovered. London: Chatham House, 2006.

6 "The Forgotten Swamp: Navigating Political Islam", Middle East Policy Council Journal 9. 2002, http:// www.blackwellpublishing.com/content/BPL_Images /Journal_Samples/mepoio6I-I924 9 2 057\%5 C057.pdf (I7.IO.20II).

7 Ibid.

8 Bruinessen, Martin V. Agha, Shaikh and State: The Social and Political Structures of Kurdistan. London/New Jersey: Zed Books Lt, I992.

9 Ibid.

Io McDowall, David: A Modern History of the Kurds. London: I.B. Tauris \& Co Ltd, I997.

II Wimmer, Andreas: Nationalist Exclusion and Ethnic Conflict: Shadows of Modernity. Cambridge: Cambridge University Press, 2002.

I2 Rydningen, Even N.: «Kryssende lojaliter, konkurrerende autoriteter - stat, stamme, religion og nasjon blant kurdere i syriske Jazeera. Bergen: Universitetet i Bergen, 2009

I3 Wieland, Carsten: Syria at Bay: Secularism, Islamism and «Pax Americana». London: Hurst, 2006.

I4 Oversettelsene fra Koranen er hentet fra Berg, E.: Koranen / tilrettelagt i oversettelse av Einar Berg. Oslo: Universitetsforlaget, I980.

I5 Ibid. 